\title{
WELCOME TO ESTONIA! FROM THE FOLK THEORY OF EMOTIONS AND CHARACTER TRAITS TO BRAND ESTONIA
}

\section{Ene Vainik \& Heili Orav}

\begin{abstract}
The article aims to (re)construct the possible correlation of two folk theories of the Estonians - the theories of character traits and emotions. The case study is based on two separately conducted experiments: Heili Orav collected Estonian lexis on characteristic personality traits and Ene Vainik collected emotion lexicon. The authors attempt to determine the relationship between töökas 'diligent' or 'hard-working' as the most prototypical personality trait and viha 'anger' as the most typical emotion of the Estonians.
\end{abstract} Key words: folk theory, character traits, emotions, hard-working, anger.

\section{INTRODUCTION}

Welcome to Estonia! Constructing Brand Estonia and the marketing strategy for Estonia has been among the most sensational campaigns of recent years. Foreigners are presented a view of Estonia as a positively transforming country. In this active campaign of selling ourselves the Estonians emphasise these basic native qualities like diligence, or being hard-working, ambitiousness, but neglect mentioning the negative characteristics of Estonians like envy, reticence, emotional apathy or hidden anger. Yet, all these qualities also seem to be inherent in the nature of a typical Estonian.

In the following article we will not discuss the folk theory deliberately construed by Brand Estonia creators, instead we will focus on the popular theory about being an Estonian, which exists and is reconstructed in language and through that in the collective mind of the Estonians. The Estonian proverb mis keelel, see meelel (lit. what is on your tongue is also in your mind - "what you say is what you think') is a popular belief that will serve as the initial theoretical premise of the empirical studies that the following article is based on: the active vocabulary that is readily used by languagespeakers (i.e. what you say, lit. what is on your tongue) contains 
concepts that prevail in the common knowledge of this domain (i.e. what you think, lit. what is in your mind).

This article is, in fact, based on two separately conducted studies, which, however, follow the same methodology, by the two authors Ene Vainik has explored the emotion vocabulary of the Estonians (Vainik 2001) and Heili Orav has studied the lexica about the character traits of the Estonians. ${ }^{1}$ Both studies employed the field method (Sutrop 2001) to conduct tasks of free listing in order to determine the core part of actively used concepts associated with these domains. The analysis is based on material produced mostly by laypersons, although the folk theories will be demonstrated on the basis of different types of language data - set expressions, proverbs, etc.

The third part of the article focuses on the question whether the typical representatives of the subcategory of these two ethnic mindsets - namely, emotions and human characteristics - might be interrelated at some level. The discussion will reveal what significance this possible interrelation might have in the light of the general 'theory of folk theories'.

We believe that pointing out the views, attitudes and evaluations that are culturally transmitted by means of language and that tacitly shape our collective self-consciousness is a matter of considerable importance.

\section{WHAT YOU SAY IS WHAT YOU THINK: ANGER}

The series of listing tasks conducted in 2001 (Vainik 2001) aimed to map the words signifying phenomena of emotional life crystallised in the collectively active lexis of the Estonians. The study was conducted in the form of oral interviews and entailed the interviewing of 100 test subjects between the ages 14-88; half of them were men, half were women.

The conducted experiments were described and the results interpreted at various angles (Vainik 2002a,b,c). The most important finding in the view of this study is that the Estonian language contains four basic words for emotions - viha 'anger, hate', armastus 'love', 


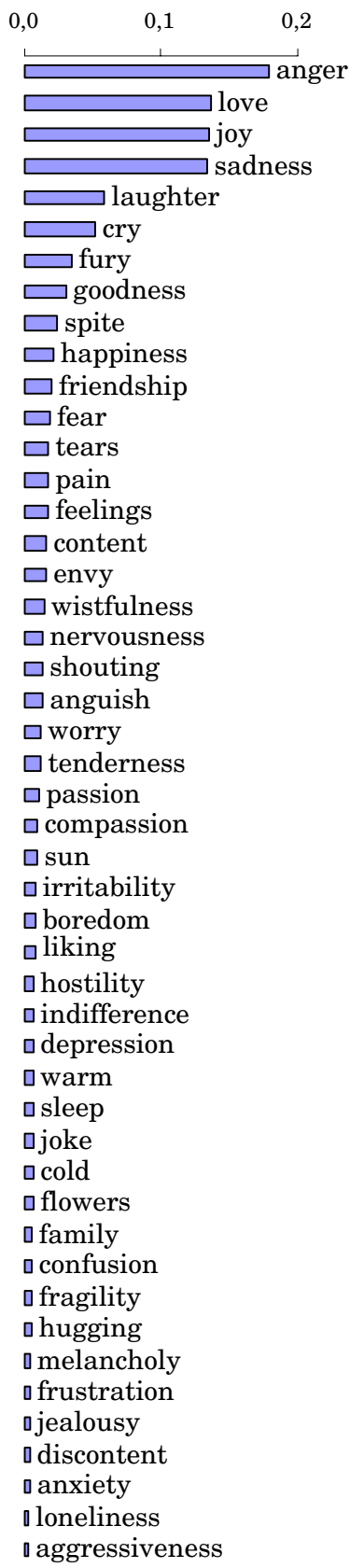

rõõm 'joy, happiness', kurbus 'sadness'. These four words form the basis of the Estonians' emotion knowledge, one that it is not dependent on the situation and is easily accessible for all (Vainik 2004).

Proceeding from the methodology of the case $\operatorname{study}^{2}$ (Sutrop 2001), the most important criterion proved to be the cognitive salience of a word, i.e. the word's tendency to come up more frequently and more prominently in tasks of free listing, where informants are asked to attempt free listing of some emotion category. The considerable variation in the index of cognitive salience was considered the most important principle that differentiates between basic terms and nonbasic terms of emotions and other vocabulary that tends to be mentioned in first positions and most frequently in the tasks of free listing (see Fig. 1).

The fact that the cognitive salience of the word viha 'anger, hate' was more prominent among the four basic emotion terms, almost to the degree that the basic terms differ from non-basic terms, was explicated by the special role attributed to anger in the emotion knowledge of the Estonians (Vainik 2002b, 2004). Anger has

Figure 1. Results of preliminary free listing of emotions (organised according to the index of cognitive salience (S) based on the frequency of occurrence and central position). 
proved to be the Estonians' most representative prototype or the most typical example of the emotion category (Fehr \& Russell 1984), which, it may be speculated, determines the general attitude towards emotions at large. L. Kästik has also arrived at the conclusion that anger is considered the most typical emotion, as the largest number of her test subjects (95\%) answered affirmatively to the question 'Is anger an emotion?' (Kästik 2000)

Anger also proved to be the most representative example of negative emotions. ${ }^{3}$ As the best example of this category, it was even more salient - it was mentioned more frequently, and among the first words. The negative valence attributed to anger appears to apply to the entire emotion category of the Estonian speakers (Vainik 2002b). The attitude towards emotions in the Estonian folk psychology is expressed by phrases like ärgem laskugem emotsioonidesse (lit. 'let's not descend into emotions'), representing orientational metaphor GOOD IS UP / BAD IS DOWN (Lakoff \& Johnson 1980: 16), which categorises emotions among negative phenomena. The expression emotsioonid lõid üle pea kokku (lit. 'emotions closed in above one's head') places the subject of the expression in an even more vulnerable position beneath the 'bad', which is, of course, doubly bad. Furthermore, the latter expression describes the emotions as an uncontrollable mass of liquid that overpowers humans. The popular conceptualisation thus categorises both anger and emotions as such among the condemnable and dangerous rather than among useful phenomena.

Even though in tasks of free listing anger emerged as a prototype of negative emotion, the attitude towards anger was also somewhat ambivalent. On some occasions, anger was categorised among positive emotions and on others among both positive and negative emotion categories (Vainik 2001). Such divergence of evaluations indicates that the general negative meaning of the word viha 'anger' may be multilayered:" ${ }^{4}$ e.g. the socially condemnable or objectionable aspect of anger may appear as a component of its general axiological negativity, whereas the unpleasant feeling may appear as another component.

Next to the evaluations that indicate the level of these social and hedonistic qualities, anger may also be evaluated as positive, or at least useful, on a scale of individual usefulness/harmfulness, since 
it enables the subject to move towards one's set goals, asserting oneself $^{5}$ or seek revenge for injustice or dishonouring (the justified, sometimes even sacred anger). In the latter context, some authors argue, anger is classified even among the moral emotions (Haidt 2003). Let us remember that in the history of humankind, class anger that moved the crowds has caused various social uprisings.

In the course of a detailed study into the Estonian emotion vocabulary (Vainik 2004), where the subjects were asked to evaluate the meaning of a word on a scale of opposite extremes, a considerable number of subjects (58\%) found, either as a primary or secondary evaluation, that anger motivates them; among the subjects who were on that opinion there were more men ( $66 \%$ of all male test subjects) than women, of whom only half thought of anger as motivating. Nevertheless, only four out of the hundred test subjects evaluated anger as, at least to a certain degree, a pleasant emotion.

While listing the emotions, the test subjects revealed a tendency to list the basic terms as antonymic pairs: listing 'anger' was often followed by listing 'love' (and vice versa) and listing 'joy' was followed

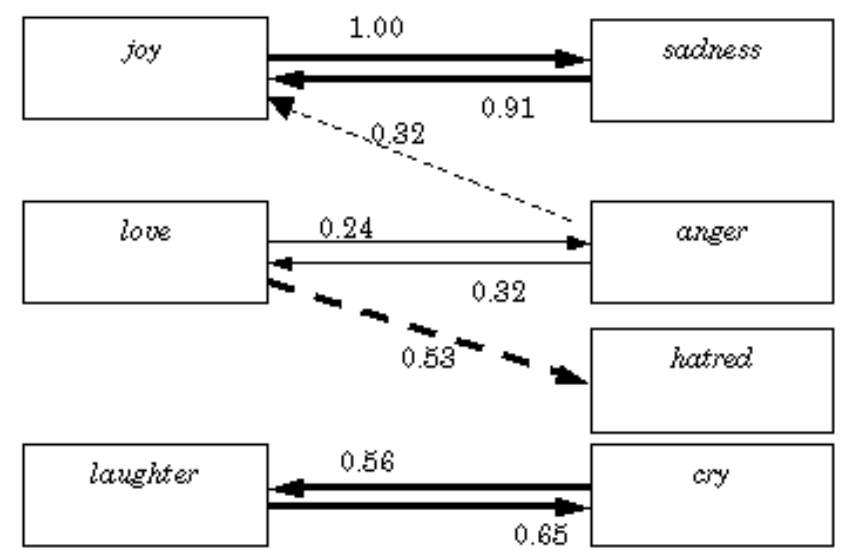

Figure 2. The interrelation of emotion terms formed as a result of the free listing of antonyms. Decimals indicate the relative strength of the relations, the dashed lines mark asymmetric oppositions. 
by 'sadness' (and vice versa). Evidently, at the basic level, the emotion knowledge is arranged as binary oppositions, i.e. in lexical terms expressed in an antonymic relationship. A mentioning of one component of the pair triggers the listing of the opposite emotion, which appears to be a case of conceptual priming (Tulving \& Schacter 1990), i.e. the opposition of emotion plays an important role in the system of semantic emotion knowledge (conceptual association) regardless of the results of experiments on self-reported emotions which claim that positive and negative emotions "do not contrast, but associate mutually in every possible way" (Allik 1997). ${ }^{6}$

A separate experiment for investigating the antonymic relationships (results are presented in Fig. 2) revealed that the most frequently occurring antonyms for 'anger' are 'love' and 'joy', which are equally popular, whereas 'anger' (together with 'hatred') is the only and most important antonym for 'love'. This interrelated system of antonymic relationships between the basic terms of emotions has led to a speculation that in the Estonians' consciousness anger exists in two submeanings. ${ }^{7}$

One of these is viha $a_{1}$ ('anger'), a relatively short-term intrapersonal state of mind (not necessarily targeted at a human object, as the object might be e.g. a situation, an incidence or quasiliving). In this case, viha 'anger' contrasts rõom 'joy' as another relatively shortterm and basically intrapersonal emotion, and is synonymous with vihastamine 'growing angry' or 'getting frustrated', and its close synonym is raev, or 'fury'.

$V i h a_{2}$, or 'anger, hate', which takes armastus 'love' as its antonym and vihkamine 'hatred' as its synonym (vaen 'animosity' or vimm 'grudge' may be regarded as its closer synonyms), appears to be perceived as long-term or infinite; the emotion is probably also more interpersonal, i.e. targeted at or related with a live human object.

As to the intra- or interpersonal dimension, the underlying meanings of the concept viha remains somewhat unambiguous, since viha associated with feelings of frustration can be, and often is definitely experienced with fellow humans (e.g. Vihastasin poes kassapidaja peale, kes mind saatis kurki üle kaaluma, selle asemel, et seda ise teha, 'I got frustrated at the cashier who sent me back to weigh the cucumbers instead of doing it herself'); analogously, viha ${ }_{2}$, mani- 
fest as a long-term disposition, can be experienced also with subjects (e.g. authorities, media) or phenomena (e.g. Kooli ajal ma vihkasin VTK normide täitmist, 'At school I hated having to meet the standards of physical education'). For the Estonians, the word viha seems to be semantically complex ${ }^{8}$ and entail both meanings: momentary as well as long-term and both intra- as well as interpersonal emotion. In the present day the active meaning of 'anger' associated with interpersonal relationships seems to be of primary importance, whereas its antonymic relationship with the word armastus 'love' is symmetric and was mentioned in variation of the close synonym marking continuous activity vihkamine 'hatred' Etymologically, the meaning referring to the intrapersonal experience appears to be older, since the earlier meaning of the Estonian word viha is connected with taste ('bitter' or 'acrid'), which definitely was a personal and momentary experience.

Even though it is one of the basic emotion terms in the Estonian, which next to cognitive salience at large corresponds to also other criteria of the basic vocabulary (Sutrop 2000), such as morphological simplicity, signification of the basic level object or phenomenon in knowledge structure, its applicability in all types of contexts (Vainik 2002c), 'anger' does not correspond to the principle of originality of the basic terms proposed by A. Cruse (2000:137). The word viha in the Estonian language was not originally an emotion term, since the word has denoted, and still does, a flavour of bitter or acrid (e.g. Põdrasamblatee on viha aga tõhus rahvaravim, lit. translated as 'Reindeer moss is a bitter but effective herbal remedy'). It is also likely that before the quality of flavour, the word has signified 'inedibility' as a category of experience which combines an unpleasant tasting experience and unpleasant consequences, such as a stomach ache. According to the etymology of the word proposed by Sutrop, the root vih (*viša) has initially signified the green colour (cf. Finnish vihreä, Sutrop 1996: 665). This claim is not entirely inconsistent with the word viha as a cognitive category of inedibility: the root has existed in the Estonian language since the time of foraging, especially considering that, for example, in terms of berries, their green colour and inedibility do coincide. The archaisms kü̈̈neviha (dirt from under fingernails that has entered a wound after scratching the wound), or maaviha, (dirt or soil from the ground that has entered a wound), for example, may not have a con- 
notation of being bitter or green, but are inedible and may lead to bad consequences, such as e.g. sepsis. Suggestive of the fact that the emotion term viha in the meaning of experience of taste has been preserved in the collective subconsciousness of the Estonians is the association of constrained anger with bitter taste (e.g. ütles sapiselt, mõrult, 'said bitter words').

The way how the words are arranged (or not) in the grammar of a language is often suggestive of how the speakers of the language conceptualise or mentally manipulate these phenomena in the given language and culture. In its grammatical association potential, viha 'anger' is a mass noun, since the Estonian word cannot be expressed in plural form (*vihad, e.g. *Impulsiivse inimese vihad vallanduvad ettearvamatult, lit., '*The angers of an impulsive person flare up unexpectedly'). It appears to be understood by the Estonians as an unbounded substance rather than physical thing. In case a bounded dose of viha 'anger' is referred to, the compound word vihahoog, or 'burst of anger' is used. Similarly to anger, emotion words like armastus 'love', häbi 'shame', kurbus 'sadness', uhkus 'pride', etc. do not take plural forms. Expression by mass nouns rather than count nouns appears to be characteristic of emotions in general. ${ }^{9}$

Viha 'anger' as an emotion is attributed to oneself or some other person by the use of an adjective vihane 'angry'. E.g. Jonniv laps oli ühtaegu vihane ja onnetu. Pikapeale läks ka isa vihaseks. 'The whining child was both angry and unhappy. As the whining continued, the father grew angry as well.' The derivation of the adjective vihane by means of the productive -ne suffix in the Estonian language differs from the derivation of adjectives from other emotion terms. ${ }^{10}$ Next to its other meanings, the-ne suffix suggests the given substance's momentary contact with the outer surface of an object (cf. porine, mullane, 'muddy, earthy') or a concentration of something in the substance (cf. mürgine 'venomous', rasvane 'greasy', soolane 'salty')(EKG: 565-566). The derivational pattern thus reveals that viha is mentally associated with substance, be a contact with it external and momentary, or internal and continuous.

The nature of viha 'anger' as a substance, even a liquid substance, in the Estonian mind is demonstrated in a metaphorical use of language based on conceptual metaphor ANGER IS A HOT LIQUID IN A CONTAINER (Lakoff 1987; in Estonian see Õim 1999). For exam- 
ple, ta vahutas vihast 'anger bubbled up in him', kees vihast üle 'anger boiled over', plahvatas vihaga 'burst in anger', valas oma viha välja 'poured out his anger', etc. Such a conceptual metaphor, where the substance like viha 'anger' is associated with heat, and as a result an overpressure in a sealed container, is not only characteristic of the Estonian language, but is used in a number of other languages (Kövecses 2000).

In the light of the above, it may be concluded that based on the data obtained from free listing tasks, viha 'anger' is the most prototypical emotion for the Estonians, who see the concept as contrasting armastus 'love' on the one hand and rõom 'joy' on the other. It occurs to be a negative emotion capable of increasing one's action potential. Relying on other linguistic data (association potential, etymology, metaphorical use of language) it is possible to argue that viha 'anger' as an emotion is unbounded in conceptualisation, a substance that has neither beginning nor end. It tastes bitter or like bile, may be expressed as fits, it may become visible in the outside, boil over from inside, bubble up or flare up. Anger appears to be a substance that occurs in different forms (such as water may occur in liquid, gaseous or solid form), the "calorific value" or energy potential of which is relatively high. ${ }^{11}$ The so-called folk theory of viha 'anger' presented above is an abstraction that not all Estonianspeakers might be aware of. Likewise, some Estonians might disagree in whether anger is the most prototypical emotion or not. ${ }^{12}$ The fragments of the folk theory on viha 'anger' and emotions, derived from the Estonian language data, basically converge with the humoral theory (Geeraerts \& Grondelaers 1995).

The topicality of anger in the emotion knowledge of an average Estonian is something that sets us apart from other cultures. Free listings with speakers of other languages,${ }^{13}$ for example, have listed as the emotion prototypes 'joy' (Belgians, French, Italians, Swiss), 'happiness' (British, Canadians), love' (Turks), 'sadness' (Japanese, Indonesians, Surinamese), or 'fear' (Dutch). Only the Finnish, like the Estonians, consider 'anger' as the most typical emotion (Tuovila, 2005). 


\section{WHAT YOU SAY IS WHAT YOU THINK: TÖÖKAS 'HARD- WORKING'}

In autumn and winter 2003-2004 Heili Orav conducted a series of free listing experiments among the Estonians in order to determine the vocabulary of personality traits. The experiment included an equal number of men and women, the total of 100 persons between the ages 14-90. The experiment consisted of four parts, where subjects were asked to list the first adjectives that come to their mind i) about human nature in general, ii) about the personality of a likeable/unlikeable acquaintance, iii) about the personality of a typical Estonian, and iv) about the respondent's own personality. The latter two parts, in turn, consisted of various tasks: the test subjects were asked to specify the likeable and unlikeable personality traits of the Estonians and of themselves.

The experiment yielded the total of 5,461 expressions. Whereas a lot of expressions were repeated and some of them were not connected with character, the material for our analysis consists of 1,271 different lexical units. As to the word classes, the most frequently occurring markers of personality traits were adjectives, nouns were mentioned on 223 occasions and verbs on only 26 occasions.

While the verbal productivity varied throughout the tasks considerably (0-58), the listing about the personality traits of the Estonians was relatively even, as the respondents found this task relatively easy. It appears that the Estonians may have problems with accurately characterising themselves or their neighbours, but the nature of a typical Estonian seems to be relatively fixed in people's mind.

The most frequently listed words should signify the most important personality traits in a given culture area. Among the personality traits listed in all the experiments, the most frequently mentioned one was töökus 'diligence, hard-workingness' - the adjective töökas 'diligent, hard-working' was mentioned on 150 occasions. It is notable, that the adjective töökas is derived from the stem töö 'work' with a productive suffix - kas and translates literally as 'worky' - a property of a person who uses to work a lot. 
The below table will present an overview of the most frequently mentioned words, which, next to diligence, cast light on other aspects of human behaviour and characteristics that the speakers of the Estonian language have noticed about their fellow countrymen.

\begin{tabular}{llr} 
Word: & & Popularity: \\
\hline töökas & hard-working & 150 \\
sõbralik & friendly & 109 \\
tark & wise & 86 \\
abivalmis & helpful & 85 \\
kade & envious & 82 \\
laisk & lazy & 78 \\
kinnine & reticent & 68 \\
ilus & beautiful & 62 \\
aus & honest & 60 \\
lahke & kind & 60 \\
kuri & cruel & 51 \\
edasipüüdlik & ambitious & 47 \\
tagasihoidlik & modest & 47 \\
rahulik & peaceful & 46 \\
hea & good & 45 \\
óel & vicious & 35 \\
rumal & stupid & 34 \\
ahne & greedy & 33 \\
rõõmsameelne & optimistic & 33 \\
hooliv & caring & 32 \\
lõbus & joyous & 32 \\
julge & courageous & 30 \\
jonnakas & stubborn & 29 \\
sportlik & athletic & 28 \\
mõistev & understanding & 27 \\
egoistlik & egoistic & 26 \\
enesekeskne & self-indulgent & 26 \\
endassetõmbunud & introvert & 26 \\
pahatahtlik & malevolent & 26 \\
omakasupüüdlik & selfish & 25 \\
tasakaalukas & composed & \\
& &
\end{tabular}

Table 1. Frequency count of the free listing experiment (frequency 18+n). Table continued on the next page. 


\begin{tabular}{llr} 
Word: & & Popularity: \\
\hline ülbe & arrogant & 25 \\
avatud & open & 23 \\
heatahtlik & benevolent & 23 \\
enesekindel & self-confident & 22 \\
kohusetundlik & scrupulous & 22 \\
otsekohene & blunt & 22 \\
pikk & tall & 22 \\
sihikindel & purposeful & 22 \\
valelik & deceitful & 22 \\
auahne & highflying & 21 \\
kannatlik & patient & 21 \\
armas & lovely & 20 \\
halb & bad & 20 \\
seltsiv & sociable & 20 \\
andekas & talented & 19 \\
armastav & loving & 19 \\
hoolimatu & careless & 19 \\
kena & nice & 19 \\
paks & fat & 19 \\
tige & spiteful & 19 \\
aeglane & slow & 18 \\
intelligentne & intelligent & 18 \\
närviline & nervous & 18 \\
siiras & sincere & 18 \\
ükskõikne & indifferent & 18
\end{tabular}

Table 1 (continued). Frequency count of the free listing experiment (frequency 18+n). Table continued from previous page.

As indicated, the listing experiment described above consisted of various tasks, one of which required that the test subjects characterise the Estonians in general and distinguish between the likeable and unlikeable personality traits of the Estonians. As a result, the Estonians were characterised by the total of 1,077 expressions, of which the most frequently listed response töökas 'hard-working' was mentioned on 96 occasions (see Table 2). Hille Pajupuu has repeatedly arrived at the same result in her comparative study of the 


\begin{tabular}{llr} 
Word: & & Popularity: \\
\hline töökas & hard-working & 96 \\
kade & envious & 63 \\
kinnine & reticent & 52 \\
edasipüüdlik & ambitious & 30 \\
sõbralik & friendly & 24 \\
jonnakas & stubborn & 23 \\
rahulik & peaceful & 23 \\
tagasihoidlik & modest & 23 \\
ahne & greedy & 21 \\
abivalmis & helpful & 17 \\
omakasupüüdlik & selfish & 15 \\
enesekeskne & self-indulgent & 13 \\
aus & honest & 12 \\
tark & wise & 12 \\
visa & tenacious & 12 \\
aeglane & slow & 11 \\
egoistlik & egoistic & 11 \\
laisk & lazy & 11 \\
sihikindel & purposeful & 10 \\
tasakaalukas & composed & 10 \\
tuim & insensitive & 10
\end{tabular}

Table 2. Prototypical personality traits of the Estonians

Estonians and the Finnish (Pajupuu 1994, 1995, 2005). ${ }^{14}$ Therefore, this study confirmed and supported the autostereotypical concept characteristic of the Estonians.

The diligent self-image of the Estonians seems to root in distant history. In 1923 Andrus Saareste characterises the Estonians in the preface to Wiedeman's dictionary: “The Estonians are serious, somewhat phlegmatic, often also choleric by nature; they are clearly individualistic, independent, and pragmatic, persistent and strong in work and enterprise, often obstinate and wilful. The Estonians are passionate about their work..." (Saareste 1923).

It is logical to assume that people work and are diligent in order to provide sustenance and satisfy their material needs. Another angle 
to the importance of work and working can be described in psychological terms: work attributes meaning or significance to a person's life; it is a part of an individual's identity, helping to achieve and preserve self-confidence, status and sense of achievement (Snir \& Harpaz 2002).

The fact that work and hard-workingness are important for the Estonians from the aspect of self-identification, is demonstrated, for example, in the answer to a commonly asked question: Kes sa oled? 'Who are you?' - most often, people answer this question by naming their job or occupation. In the Estonian language the word for job or occupation is elukutse (lit. calling in life), to be working at some field is expressed by the phrase järgima elu kutset, or "to follow one's calling in life".

In addition to diligence, the prototypical characteristics of the Estonians include envy and reticence. Envy is expressed in ironic terms in popular sayings like eestlase parim toit on teine eestlane (lit. 'for an Estonian, the best food is another Estonian') or uurib naabri rahakotti (lit. 'is peeking into one's neighbour's wallet'). The proverb rääkimine höbe, vaikimine kuld ('speech is silver, silence is golden') indicates that reticence used to be a valued personality trait in the past.

Among the rest of the more popular adjectives used to characterise the Estonians, 12 words are commonly regarded as having positive and 9 as having negative evaluation. To compare, a study conducted some ten years ago revealed that the Estonians regard themselves highly - the only qualities that were considered as negative were reticence and being unemotional, while envy and greed were not even listed among the negative personality traits (Pajupuu 2004). Thus it seems that, first, envy is a quality that has been attributed significance only recently, and, second, the self-esteem of the Estonians has somewhat decreased over the past ten years.

Although the main purpose of the above listing was not specifically to determine the autostereotype of the Estonians, the word töökas 'diligent' or 'hard-working' clearly represents the most prototypical personality trait of an Estonian owing to its frequent occurrence, thus forming the central element of the folk theory about being an Estonian. 
Among the important qualitative aspects of lexis about personality are the graded nature of personality concepts (i.e. the degree of some quality may be larger or smaller) and the nature of the scales. The scales are generally divided into positive and negative values In personality traits, however, the graded scale is not so obvious. It is difficult to find an opposite adjective for several personality traits, even though an implicit scale may exist. True, it may prove difficult to define antonyms for kade 'envious', vassija 'distorter of truth', or klatšija 'gossiper', whereas the degree of these traits can be measured by quantifiers (natuke, pisut, 'somewhat') and adverbs (väga 'very', oudselt 'terribly', liiga 'far too', etc.).

Secondly, considering that the scales have two "ends", can they be characterised as positive and negative? For instance, self-confidence is generally considered a positive personality trait, the lack of it is considered negative, but a person may be also "overly confident" (the degree of self-confidence rises above the average or what is considered normal in a given situation) and this is perceived as a rather negative quality.

It should be noted here that the positive and negative evaluation associated with personality traits does not coincide with the good/ bad categorisation. Semantically there is a huge difference between labelling a person (or the person's character) good / bad or positive / negative. To say that someone is a good person is not the same than to say that he or she is a positive person. A positive frame of mind is a personality trait that signifies a person's attitude towards the world, the person's confidence and optimism. To say that someone is a good person refers to the general pattern of the person's characteristic traits, or the assessment of the degree to which the speaker finds the given person's qualities acceptable or useful. In the latter case the utterance is a subjective evaluation of the speaker. ${ }^{15}$

The most prototypical quality of the Estonians - töökus 'diligence' is supported by other concepts related to the domain. The data of all the free listing experiments show that the following words function on the scale TÖÖKUS 'DILIGENCE' - laisk 'lazy', laisavõitu 'sluggish', töökas 'diligent', töörügaja 'hard-working', tööarmastaja 'industrious', tööhimuline 'zealous worker', töönarkomaan 'workaholic', rabaja 'driven', ületöötav 'overworking', ületöötanud 'overworked', liiga töökas 'overly hard-working'. The two extremes of 
the scale could be marked by adjectives laisk 'lazy' and töökas 'diligent', which are considered as binary oppositions in actual language usage. The word töökas 'diligent' in this opposition marks the quality of positive value. For the Estonians, the positive value of being hard-working or diligent is further expressed by proverbs such as Vara üles, hilja voodi, nõnda rikkus majja toodi, lit. 'Waking up early, going to bed late, is a road to wealth', or Mis täna tehtud, see homme hooleta, 'If you do it today, you won't have to worry about it tomorrow'.

The scale anchored between the two extremes of positive and negative value poses the question about the degree of the phrase liiga töökas 'overly hard-working'. The question lies in the adverb 'overly' as an excessive, incomprehensible, even inhuman, abnormal degree of diligence, the kind that does not associate with ordinary perception, and is condemned. Therefore, the language community has adopted new words to replace the phrase 'overly hard-working', such as ületöötav 'overworking' and töönarkomaan 'workaholic', which are suggestive of excessive working and are perceived as negative qualities. The Estonian lore also includes sayings about excessive working, such as Liigne agarus on ogarus 'Too much zeal is madness', or Ega töö jänes pole, et eest ära jookseb 'Work is not a rabbit that tries to run away."

The listings data thus constitute two scales of words connected with work: töönarkomaan/töökas 'workaholic/diligent' and töökas / laisk 'diligent/lazy', where the positive adjective töökas 'diligent' is positioned in the middle and the words töönarkomaan 'workaholic' and laisk 'lazy' in the two extremes are perceived as negative adjectives (see Fig. 3). Compared to the extremes of the scale, töökus or 'diligence' proves a central and hence normative personality trait.

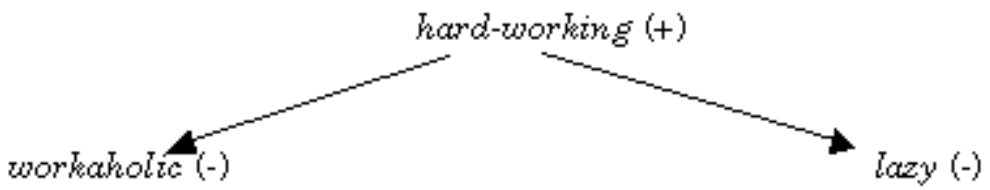

Figure 3. Chart characterising the degree of dedication to work. 
Psychologists have found that the quality that the Estonians value most is hedonism (Aavik \& Allik 2002). This may explain the condemning attitude towards excessive working. If a person is doing a job that $\mathrm{s} /$ he can handle, enjoys or finds pleasure in, and is not doing it out of external pressure in order to show others how smart, capable, talented, or rich and famous $\mathrm{s} / \mathrm{he}$ is, then the person is not threatened by burnout syndrome, has enough time and energy for enjoying his/her life, and is not regarded as a workaholic.

Psychologists have also discovered that diligence plays an important role in the typical value system of the Estonians, in which it is perceived, together with rationality, cleanliness, discipline, decency, and frugality, as one of the components of the factor expressing conservatism (Aavik \& Allik 2002). The latter fact confirms the normativity of diligence concluded on the basis of language data in the self-perception of the Estonians.

All the individual differences significant in terms of social communication become fixed in language over time: the more remarkable and significant a quality is, the greater is the probability of the existence of a separate word signifying the quality (Goldberg 1993; John 1990), and the greater is the amount of concepts associated with it.

The above considerations suggest that the most important human characteristic for the Estonians is diligence. The semantic field of the word 'diligence' entails the entire concept together with the history of working, evaluations, topical associations, etc. These components are no longer of equal significance for a modern Estonian, as there have been periods in the history of Estonia, where the social situation has influenced the attitudes towards work. For example, the vocabulary actively used in referring to work in the Soviet time (Simka 1950) has largely lost its topicality by the present day.

In modern Estonian society the meaning of the word 'diligence' is rather associated with ambitions and career. The Estonians as if "measure" the efforts that people around them make in their professional life, the intensity that people aspire towards some goal whereas it is not only other people's behaviour that is measured but also whether a person wishes and wants to achieve something at all. Ambitiousness is demonstrated by a number of words, men- 
tioned in a free listing task, that signify the attitudes and behavioural patterns connected with achievements and competitiveness: edasipürgiv, edasipüüdlik 'aspiring', ambitsioonikas 'ambitious', auahne 'highflier', karjerist 'careerist', karjäärihimuline 'go-getter', läbilöömisvõimega 'succeeding', pealehakkaja 'enterprising', pingutav 'striving', pü̈̈lleja 'aspiring', saavutushimuline 'ambitious', sihikindel 'determined', eesmärgikindel 'goal-oriented', eesrindlik 'progressive', tahtejõuline 'strong-willed', trügija 'pusher, go-getter', tõusik(lik)'upstart', tippupürgiv 'striving', and their antonyms: mitte edasipürgiv 'unaspiring', pole auahne 'unambitious', vähe auahne 'lacks ambition', vähe edasipü̈̈dlik 'little aspiring'. In addition, 'diligence' can be associated with a number of various personality traits that may be (and often are) important at working, such as visa 'tenacious', vastupidav 'enduring', sitke 'tough', konkreetne 'specific', ratsionaalne 'pragmatic', kohusetundlik 'responsible', osav 'skilful', korrektne 'punctual', etc. Here it is possible to speak about words that signify a person's professional abilities, such as professionaalne 'professional', koostöövalmis 'cooperative', süsteemne 'systematic', organisaator 'organiser', etc. Such interrelation of human characteristics also points to the fuzziness of the boundaries of the semantic field of the concept; in the scope of this article the topic was only briefly addressed and it definitely deserves more detailed study.

In sum, it can be said about the popular self-image of the Estonians that the words, phrases and sayings topical in language on the one hand point to the prototypical nature of 'diligence' as a characteristic trait of an Estonian, but on the other hand are suggestive of the ambivalent attitude towards the trait, since the collective memory of the Estonians has stored different cultural layers of mentalities connected with the social role and status.

\section{ARE THE ESTONIANS ANGRY ABOUT WORKING OR HARD-WORKING BECAUSE OF ANGER?}

Psychologists have no doubt that it is reasonable to assume the link between personality traits and emotions that are experienced frequently (Nõlvak \& Valk 2003). Further studies have revealed that, indeed, frequent experiencing of positive emotions is correlated to 
extraversion, and frequent experiencing of negative emotions is correlated to neuroticism, and the same has been concluded in the studies among the Estonians (Allik \& Realo 1997). Then, assuming a link between the autostereotypical national character and prototype emotions of the Estonians could also be ventured.

This study, however, was more straightforward in the exposition of the problem: instead of the general statistical factors (negative affect, responsibility) the authors are investigating two specific representatives from either categories (the emotion term viha 'anger' and the personal adjective töökas 'diligent'), owing to their remarkable frequency in the free listings of personality traits and emotions.

According to the above overview, an average Estonian considers 'diligence' as the most typical characteristic feature of the Estonians, and 'anger' as the most typical emotion of the Estonians. Does this form a typical triangle of opinions - Estonian-anger-diligent? Or does this call for a question what is the significance of the typical representations of these categories and whether the salience of a concept in collective knowledge stands for the salience of the phenomenon in the collectively perceived reality? Does it mean that the parallel salience of two phenomena indicates that these phenomena are interrelated? Are the prototypes of the phenomena ('anger' and 'diligence') interrelated (e.g. as elements of a given folk theory), or are they associated through the reality reflected in the surroundings?

If we take an apple as the most typical fruit and potato as the most typical vegetable, then common sense compels us to conclude that these objects are perceived as typical owing to their frequent cooccurrence in the garden and on the table. What is the importance of 'anger' and 'diligence' as the typical representatives of the given categories for the surrounding reality? Indication of their frequent co-occurrence on our behavioural landscape?

There are more questions than can be answered on the basis of the conducted research. Data collected by the present moment, however, enable to observe and compare the cognitive salience of the words töökas 'diligent' and viha 'anger' in different socio-demographic groups, and determine whether the working place as a site 
for a listings interview favoured or obstructed the listing of viha 'anger' as the typical emotion. After presenting the results, the relation of the phenomena in the light of the theory of folk theories will be discussed.

The authors tentatively compared the cognitive salience of emotion terms and adjectives "generally used for describing" the Estonians in independent free listing experiments for two separate groups - men and women (see Fig. 4). The word viha 'anger' was the most popular typical emotion and the word töökas 'diligent' was at the top of the typical personality traits of the Estonians among both groups.

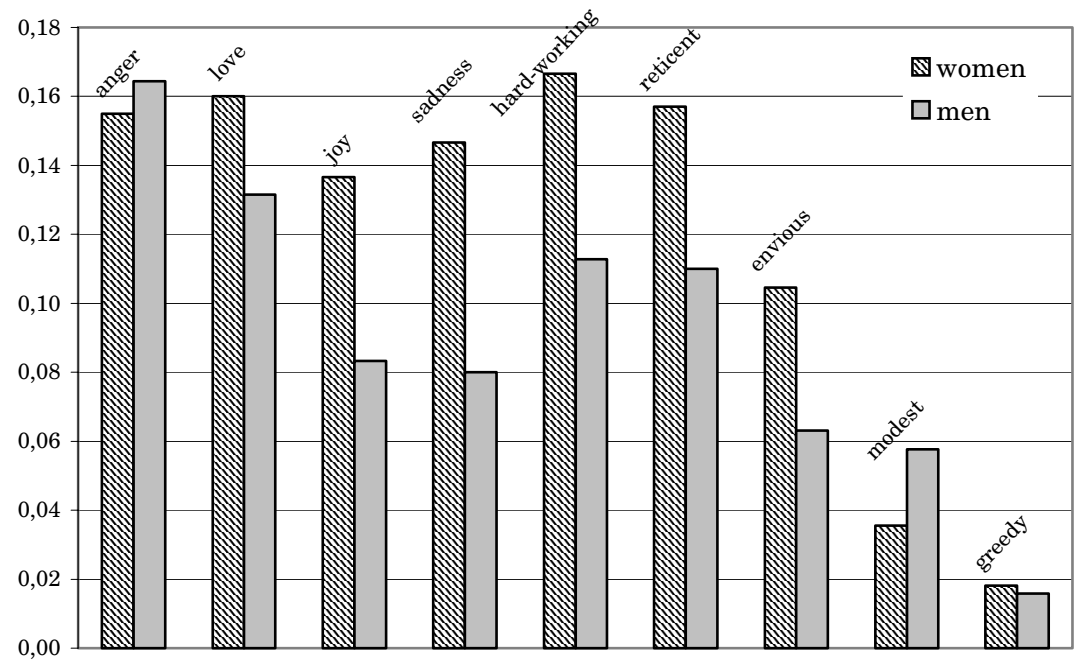

Figure 4. Results of free listings of emotion terms and typical personality traits in comparison of men and women, organised according to the index of cognitive salience (S).

The listing revealed that the gender of the respondents influenced, to a certain extent, the recollection and mentioning of the typical personality traits of the Estonians. Women tend to mention all the basic emotion terms more often and in the first position, listing viha 'anger', armastus 'love', rõõm 'joy' and kurbus 'sadness', whereas 
among men, viha 'anger' is more salient than others, as 'love', and particularly 'joy' and 'sadness' are mentioned less frequently. This has led an author of this article to speculate that the basic level of emotion knowledge among the Estonian-speakers appears to have been established by women (Vainik 2003, 2004). The autostereotype of the national character of the Estonians appears to be even more strongly established by women, since the words töökas 'diligent', kinnine 'reticent', and kade 'envious' have all been listed more frequently and in the first position mostly by women, whereas male respondents perceive Estonians as more modest.

A comparison of the main results of the free listing of emotions and personality traits by genders reveals that among men the most topical concept is viha 'anger', while among women the most typical concept is that of töökus 'diligence'. Since the test subjects were asked to list the members of the category in general terms, not reflexively, it cannot be directly concluded on the basis of the available data that the Estonian men are angry and the Estonian women are diligent or hard-working. All we can do is indicate that the terms appear to be more easily available and accessible for either gender.

The results of the listing of emotions and typical personality traits of the Estonians were also comparatively analysed in three age groups (see Fig. 5). Since the age dynamics of the salience of emotion terms has been discussed elsewhere (Vainik 2003, 2004), the comparison here entailed the age salience of the words viha 'anger' on the one hand and töökus 'diligence' on the other, but also the words kinnine 'reticent' and kade 'envious'.

The youngest age group (test subjects between the ages 14-30) is characterised by a high salience of the word viha 'anger' (the highest salience in the entire experiment!), as well as the high salience of the personality trait kinnine 'reticent'. The fact that a typical Estonian is also töökas 'diligent' and kade 'envious' appears to be less topical for the young people. This age peculiarity could be explained by the fact that in the period under discussion, young people are occupied, according to the developmental tasks, ${ }^{16}$ mostly with establishing and preserving, or rupturing relationships. Viha 'anger, hate' as an emotion and kinnisus 'reticence' as a personality trait may be invoked in the young people's knowledge as the main obstacles in establishing and preserving relationships. Töökus 'dili- 


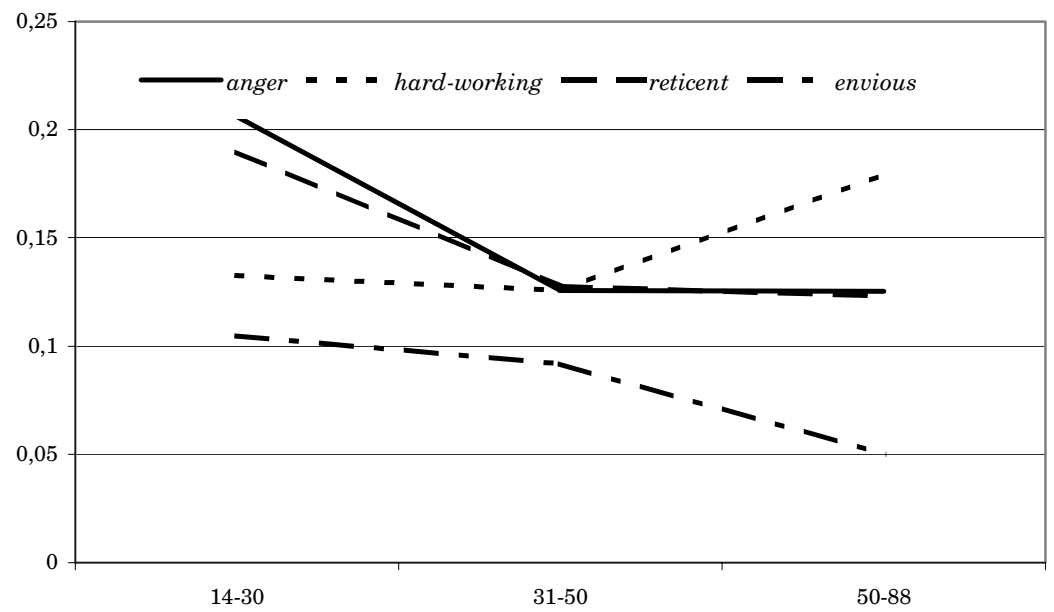

Figure 5. The dynamics of the main results of free listings of emotions and adjectives marking the personality traits of the Estonians according to age variation (based on indices of cognitive salience).

gence' and kadedus 'envy' as qualities oriented to creating and preserving/comparing resources appear to be less topical in this stage of human development.

The second age group (31-50) is characterised by a considerably lower salience of words viha 'anger' and kinnine 'reticent', and a barely noticeable lower salience of words töökas 'diligent' and kade 'envious'. It is also worth noting that the cognitive salience of the words viha 'anger', kinnine 'reticent' and töökas 'diligent' is identical: next to establishing and preserving relationships, the main developmental tasks of people in their 40s and 50s have included also the creation of resources (töökus 'diligence') and the terms pertaining to this appear to be equally topical from the aspect of development.

In the oldest group of respondents (51-90), the salience of töökus 'diligence' as a typical characteristic of an Estonian increased significantly and the frequency of listing the word kade 'envious' decreased. Apparently, the autostereotype of being 'diligent' among the Estonians is something that develops over the years. It is possi- 
ble that the high topicality of the word töökas 'diligent' in the emotion knowledge of older Estonians results from their personal experience of a lifetime of working (another important consideration is, of course, the fact that their most active working years coincided with the Soviet period, when diligence was particularly valued) and from the accumulated resources. But the advancement of years appears to develop a view that resources are easier to achieve through diligence rather than with envy. Viha 'anger' and kinnisus 'reticence' as the most typical emotion and personality traits of the Estonians, respectively, are still topical, but the frequency of listing the terms is the same than in the previous groups.

An observation of the age dynamics of the salience of only two words viha 'anger' and töökas 'diligent' in the three groups reveals a unique kind of mirror symmetry: in mid-life the total salience of viha 'anger' (an emotion) is replaced with the total salience of töökus 'diligence' (personality trait, behavioural category). Does this mean that while advancing in age the Estonians learn to transform their energy from destructive force (anger) into constructive power (work)?

Moreover, in the view of the folk theory transmitted in the Estonian language about the nature of viha 'anger' (as having high energetic potential, but a dangerous, poisonous and indeterminate substance) it is not particularly surprising that kinnisus (lit. 'closedness, reticence') is also listed as a characteristic personality trait of the Estonians: evidently, the difficult task of transforming energy from destructive forces into constructive power is possible only in a closed system. Anger yields strength for working, but at the same time the Estonians grit their teeth (hambad ristis) and find it relatively difficult to smile and be open.

Interesting mirror symmetry becomes also apparent in the dynamics of the salience of the words töökas 'diligent' and kade 'envious': increase in the salience of töökus 'diligence' in older age concurs with a decrease in the salience of kadedus 'envy'. Does this, perhaps, mean that with the advancement in years the strategy of acquiring resources based on comparison and competitiveness (kadedus 'envy' and viha 'anger') is replaced with the strategy based on individual effort (töökas 'diligent')? For the moment, these questions remain but mere speculations that should be confirmed or refuted by further in-depth studies. 
The study also attempted to determine whether conducting the experiment at one's work place has influenced the topicality of the word viha 'anger'. Figure 6 presents comparative data on the cognitive salience of the basic emotion terms in free listing experiments, conducted at the subjects' work place (with the agreement of the board of the institution) or in other locations, such as homes, cafés, day centres, libraries.

Figure 6 indicates that the work environment has been a relatively unfavourable place for recollecting emotion terms, as the general verbal production and therefore also the proportion of repetitive expressions and the salience indices calculated on the basis of repetition tend to be lower than in non-work environment. The only exception to the rule is the word viha 'anger', which the test subjects have readily remembered even in the work environment. Apparently, the emotion terms have been easier to recollect in nonwork environment, and there are no major differences in the basic emotion terms; remarkably, though, the most salient emotion term is the word armastus 'love'.

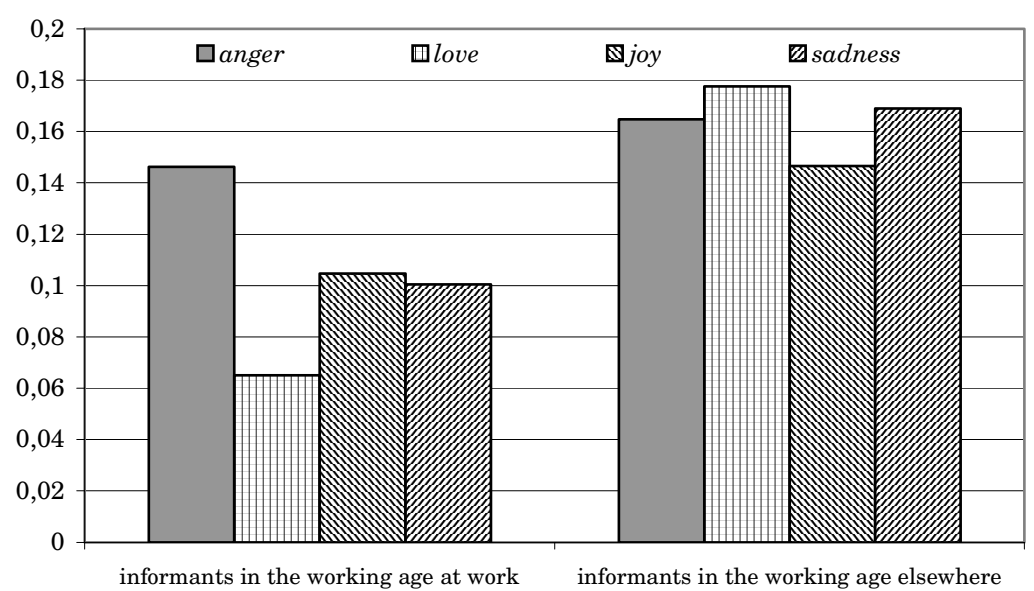

Figure 6. Cognitive salience of basic emotion terms among informants in the working age (age 20-65), in interviews at work places $(N=43)$, and elsewhere $(N=29)$. 
It seems that if a respondent is expected to think about emotions, the work environment tends to activate the concept of anger in the emotion knowledge of the Estonians, while non-work environment enables to comparatively activate all the basic level emotion knowledge (Vainik 2004). To be certain, it was verified whether the relative total salience of viha 'anger' was not conditioned by the fact that the subjects interviewed at work place included more men than women. It turned out that the gender of the respondents had no significant effect on the result, and the most conspicuous difference in the salience of words listed at work place $v s$ elsewhere was that armastus 'love' was not listed among the emotions at work place.

The results enable to hypothesise that in terms of the basic level of emotion knowledge, the work environment activates mostly the concept of viha 'anger'. It is, certainly, presumptuous to propose any final claim about the actual connection between being at work and recollecting the emotion term viha 'anger', as an independent study is required for determining the possible correlation between the phenomena.

To conclude, it is possible to agree on the basis of comparing the recollecting of the terms viha 'anger' and töökus 'diligence' in different groups and at work place $v s$ elsewhere that it is subject to dynamics which refers to the possible correlation between the phenomena. As indicated above, the phenomena that prove salient in the folk theory of national character and popular emotions may not stand in causal relations, e.g. viha on see, mis teeb eestlased töökaks 'anger is what makes the Estonians hard-working' or that töö on see, mis teeb eestlased vihaseks 'work is what makes the Estonians angry'. Elements of folk theory may associate by means of the mediated linguistically constructed reality, and the total salience of terms töökas 'diligent' and viha 'anger, hate' as members of the corresponding categories may not result from each other, but from their link to a more general phenomenon, the representatives or linguistic reflections of which they both are.

We thus conclude that both conceptualisations of the individual subjective experience (like emotions and feelings) and the qualities significant in social communication (personal characteristics, personality traits) play an important role in the collective mental 
worldview mediated by the Estonian language (see Õim 1997). At the same time, a scholar's intuition cautions that the folk models organising the categories of emotions and personality may differ in principle, since the former is primarily experiential while the latter is rather a conceptual category.

Knowledge about emotions has been passed on to us as a subjective imminent experience and only this enables to decide what feeling exactly are we experiencing at a given moment. In this diversity of subjective experiences we operate by means of emotion term present in the language, such as rõom 'joy', viha 'anger', mure 'sorrow', kurbus 'sadness', etc. Conventional ways of categorising emotional experience or attributing this to others have been established in every culture. If we say that 'he was angry', then with this utterance we will probably pass on not just the linguistic expression but also a segment of our own subjective experience. The classification of the emotion terms in nearly all languages into positive and negative, which is considered universal (Wierzbicka 1999), is largely based on the subjective preferences of emotions; some scholars have argued that these entail other evaluations of the social preference of emotions (Solomon 2002; Vainik 2004).

Our awareness of personality traits has been handed down to us in quite a different way. The knowledge of what is e.g. abivalmidus 'helpfulness', ülbus 'arrogance', lahkus 'kindness', siirus 'sincerity', or who is norija 'teaser', jõhkard 'bully', etc. is in no way learned through imminent perceptions or senses. Saying anything about someone's personality is possible only if it is compared against the personality of others or against a tacitly acknowledged norm. Personal characteristics are abstractions, generalisations, and primarily based on other people's behaviour, and are thus a part of conceptual rather than experiential knowledge. People acquire these concepts directly from language, the concepts are based on and derive their nature from the social experience of other people, not a person's internal experiences. The semantics of the words signifying personality traits are usually associated with evaluation, which is a categorising evaluation attributed on the basis of behaviour, which must be understood in the context of the background events and social expectations. It is far more complicated for an ordinary person to exactly describe an aus 'honest' person, or who a nahaal 
'an inconsiderate person' is, than to explain why some person deserves to be called that.

Many scholars have been interested in the formation of the collective worldview, including both knowledge about objects and phenomena, as well as people's shared understanding of strategies of survival or subsistence. Even the terminology used by different schools varies, including terms folk model, folk theory, cultural model or naïve theory. The linguistic term folk theory has been introduced from anthropology, in which a cultural model is defined as a cognitive model shared by a social group (D'Andrade 1987: 112). Such cognitive models function tacitly and help the people living in the given culture area to conceptualise certain phenomena for themselves and understand these more or less the same way.

It must be emphasised, though, that a 'naïve theory' of some area of life is not naïve in the sense of being primitive or immature, but that it is based on an interpretation of a long experience of a language collective rather than on academically posed hypotheses, their tentative testing or verification of claims.

In both linguistics and anthropology, such naïve theories are usually discovered while analysing the lexis established in a language; also, the collective attitude to the mediated phenomena may become evident in certain grammatical constructions and typical derivations. In the school of cognitive linguistics, however, it is commonly accepted that the so-called semantic space of language is not merely a confusion of words but that it has a relatively stable structure and it is arranged by domains or the so-called cognitive domains (see Langacker 1987; Lakoff 1987; Cruse 2000; Croft 2003). While in natural language the categorisation is based on the model of prototypical features rather than the model of sufficient or necessary conditions, it is, logically, not assumed that these domains are strictly separated in the semantic space or the so-called mental lexicon of a language (Aitchison 2003). Even naïve theories may occur in collective knowledge as fragmentary or as transversely used between domains.

Other authors, however, claim that the constituents of the worldview conceptualising the mental aspects of our lives tend to be relatively autonomous and independent. According to Apresian, for example, 
being a human is separated into at least six basic systems - physical perception ('perceive'), physical activity ('do, make'), intellect ('think'), will/wish ('want'), emotions ('feel'), and speech ('say, talk'). ${ }^{17}$ According to Apresian, a person might know or think about something or someone without perceiving this thing or person, without feeling any emotion or wish or even without doing anything (Apresian 1992).

The theory about folk theories thus argues that on the one hand such theories organise our worldview and systematise it thematically, but on the other hand, these theories may be so fragmentary, relatively autonomous from each other but also interrelated and reciprocally used. Thus, the theory of folk theories neither confirms nor refutes the possibility that the total salience of the subcategories of the folk theories about mental spheres in the system of collective knowledge may be somehow interrelated.

If we attempt to explain why anger among all the emotions and diligence among all the personality traits prevail in the folk theories of the Estonians, the following hypothesis might be set: diligence and anger are two possible effective strategies in evolutionary struggle for life. In Estonian olelusvõitlus translates literally 'the fight for being'. The fight among organisms for food, space and other vital requirements contains anger or even overt aggression and diligence as a strategy for creating resources for being and thus securing the quality of existence. The topicality of different strategies proves dependent of age, gender and context (competitiveness and struggle are relatively topical among the youth, men, and in the work environment, whereas the creation and preservation of resources is topical in the context of women, the older generation and the non-work context).

The importance of work and hard-workingness for the Estonians is certainly topical in the context of contemporary consumer race, but at the same time it may also serve as a rudiment of strong communities which established normative values from the times when the continuity of the community (i.e. providing subsistence) was directly dependent on the contribution of its working members. The emphasis on diligence and hard work in the Soviet period (the Socialist working matches and slogans like 'Glory to Work!') was the result of the needs of the Russian agrarian society, where community 
played an important role. Presently, however, the dramatically advancing mass production has destroyed the community and glorifies individualism.

It is somewhat surprising to recognise direct allusions, manifest in reflections of our civilised society, to the primitive struggle for life, which is generally associated with evolutionary processes in the uncivilised nature. Attempts to conceptualise social phenomena by means of evolutionary terms, however, are usually labelled as primitive reductionism. Perhaps we are still living in an extraordinary time, when the discussion about the ethnic disappearance of the Estonians (which is not merely a discussion but a clear and present danger, considering the negative birth rate in Estonia) hyperactivates in the collective knowledge of the people the terms 'diligence' and 'anger' signifying the strategies for creation and preservation of resources necessary for survival.

It is worth noting that the attitudes towards both anger and diligence proved ambivalent - on the one hand they are seen as positive, since these are actually efficient strategies for an individual. On the other hand, anger is socially condemned, as the general norm is to be "good" or "nice to each other", and excessive working is perceived as a pathology diverging from the social norm, which is sanctioned by linguistic labelling. Such double standards for evaluations of individuals and in general are something that appear to be a part of folk models, since in folk theory the positive outcome justifies the means and conflicting evaluations or contents are allowed.

\section{ONCE AGAIN: WELCOME TO ESTONIA!}

The above discussion about the folk theories of the mental life of the Estonians observed on the basis of the what you say is what you think principle, whether there might be any relation between the most typical emotion of the Estonians viha 'anger' and the mythical töökus 'diligence' prevailing in the Estonian frame of mind. The authors of the article did not intend to prove that the folk theories of emotions and personality traits are necessarily linked, and attempted to point out certain facts, refer to certain tendencies, pose questions and arrive at a hypothesis, which could be further tested 
in future studies. The folk theory discussed here, if tested and proved, may eventually develop into a scientific one.

The authors believe that well-developed commercial brands have something in common with folk theories - namely, they help people to orientate in real life. The representations do not need to truthfully represent reality, but they have to be established in the actual knowledge of a large part of members of a culture area. Commercial brands are consciously developed to meet the needs of their own, with the purpose to sell more. Folk theories develop spontaneously and reflect the interests of the members of a language collective: figuratively speaking, to eat more, or to get closer to the resources necessary in life. Awareness of the ethnic nature of folk theory and its attributes (including emotions) does not help us to better understand and interpret certain things about ourselves, but also to manage by means of different strategies, explain, and if necessary, justify our behaviour.

While topical concepts are reflected in collective knowledge (the active, available lexis of the Estonian language), diligence and anger do not appear to be strategies in the shared strive for survival of the whole Estonian nation, nor does the hard-workingness operate as a way of collective redemption that was promoted in the Soviet Socialist period. Instead, this is about the cunningness of our selfish genes (Dawkins 1989) to construct or openly adopt the competitive cultural model, where the success of one is interpreted as the cause of the failure of others, and where personal success is guaranteed by either working hard for creating resources by oneself or procuring these by fighting in 'anger' or 'envy' from the society.

\section{Acknowledgements}

Supported by Estonian Science Foundation grants no. 5534 and 5040.

\section{Comments}

${ }^{1}$ The overview of words connected to human characteristics will be shortly published in Heili Orav's Ph.D. thesis. 
2 The field method originates in Berlin and Kay's methodology in the 1960s. Berlin and Kay (1969) studied the cross-cultural universal regularities in the salience of colour terms.

${ }^{3} \mathrm{~A}$ separate listing task involved asking the informants to name positive, negative and neutral emotions. The most prototypical positive emotion was joy and the subcategory of neutral emotions proved artificial as it lacked salient members (words like ükskõiksus 'indifference'; kurbus 'sadness'; väsimus 'fatigue'; rahu 'peace'; and igavus 'boredom' were mentioned, but these remained beneath the level of significant salience).

${ }^{4}$ The fact that the general positive/negative nature of emotions consists of different layers of evaluations has been suggested theoretically (Solomon 2002) as well as on the basis of an empirical study by one of the authors of this article (Vainik 2004).

${ }^{5}$ Kövecses (2000) considers the concept of channelling anger into something constructive quite atypical of the present day, but suggests that it was relatively common among certain social groups in the Victorian Era. During the Industrial Revolution in the US, for example, controlled and channelled anger was tolerated and even a normative emotion for politicians, businessmen and reformers (Stearns 1994).

${ }^{6}$ Semantic and episodic knowledge of emotions appear to be organised in different ways (Vainik 2002a) and supposedly the conditions of setting up different kinds of experiments play some role in this (Vainik 2004).

${ }^{7}$ According to A. Cruse, the presence of different antonyms is one of the important criteria for polysemy (Cruse 2000).

${ }^{8}$ Compilers of the manuscript of Estonian language dictionary at the Institute of the Estonian Language relying on linguistic information, have not considered necessary to distinguish between quantitative or qualitative polysemy of 'anger' as a state of emotion.

9 There are, however, some emotion terms that can be used in plural formin Estonian, too, suggesting that for them to be conceptualised like countable things, one is capable to own many of the same kind concurrently. E.g. Väikese lapse hirmud ja rõomud on siirad ja ehedad ('the joys and sorrows of a small child are sincere and real'). The same applies to some traits of personality, e.g. Inimesed tegelevad oma norrkustega rohkem kui tugevusega ('People are more in touch with their weaknesses than their strengths.')

${ }^{10}$ The issue of emotion adjectives in Estonian is a complicated one, as the derivation of the words rõomus 'happy', hirmus 'terrifying', armas 'lovely', 
häbelik 'shy' differs from that of the word vihane 'angry, and point to a different relationship between the subject and the emotions. Many Estonian adjectives signifying emotional characteristics, such as e.g. uhke 'proud', kade 'envious' form the example for deriving secondary emotion terms instead (see Vainik 2002c).

${ }^{11}$ An exceptional emotional state is certainly jõuetu viha (lit. forceless anger) 'feeble anger'; once anger loses its high potential of energy, the expressions are like viha lahtub raugeb, 'anger abates evaporates'.

12 E.g. the test group of middle-aged informants regarded rõom 'joy' as the most typical emotion (Vainik 2003).

13 Sources: van Goozen \& Frijda 1993; Frijda, Markam, Sato \& Wiers 1995.

${ }^{14} \mathrm{H}$. Pajupuu has conducted three listing experiments: in 1991/1992, in 1996/1997, and in 2002/2003/2004. Each experiment included 150 subjects, who were asked to characterise an average Estonian with three freely chosen adjectives: "We, the Estonians, are...." The results of these listings indicate that prototypical Estonians are diligent, reticent, modest, ambitious, composed (Pajupuu 1994, 1995, 2005).

${ }^{15}$ Evaluative adjectives like good and bad are generally used in most contexts and with every noun (Orav 2000).

${ }^{16}$ According E. Erikson, young people, before turning 40, have to resolve developmental tasks individual identity vs role confusion and intimacy vs isolation. (see e.g. Erikson 1982).

${ }^{17}$ In brackets we have included the semantic primitives valid in most languages, proposed by Apresian. These are not entirely identical with the universal semantic primitives proposed by Wierzbicka (1972).

\section{References}

Aavik, Toivo \& Allik, Jüri 2002. The Structure of Estonian Personal Values: A Lexical Approach. European Journal of Personality, 16 (3), pp. 221-235.

Aitchison, Jean 2003. Words in the Mind: An Introduction to the Mental Lexicon (3rd ed.). Malden (MA): Blackwell Publishing.

Allik, Jüri 1997. Psühholoogia lihtsusest [On the Simplicity of Psychology]. Tartu: Tartu Ülikooli Kirjastus. 
Allik, Jüri \& Realo, Anu 1997. Emotional Experience and its Relation to the Five-Factor Model in Estonian. Journal of Personality, 65 (3), pp. $625-645$.

Apresjan, Jurij D. 1992. Systemic Lexicography. Tommola, Hannu \& Varantola, Krista \& Salmi-Tolonen Tarja \& Schopp, Jürgen (eds.). EURALEX '92: Proceedings, I. Fifth EURALEX International Congress, Studia Translatologica, Ser. A, Vol. 1. Tampere: University of Tampere, pp. $3-16$.

Berlin, Brent \& Kay, Paul 1969. Basic Color Terms; their Universality and Evolution. Berkeley: University of California Press.

Croft, William 2003. The Role of Domanis in the Interpretation of Metaphors and Metonymies. Dirven, Rene \& Pörings, Ralf(eds). Metaphor and Metonymy in Comparison and Contrast. Berlin: Hawthorne \& New York: Mouton de Gruyter, pp. 161-205.

Cruse, D. Alan 2000. Meaning in Language: An Introduction to Semantics and Pragmatics. Oxford \& New York: Oxford University Press.

D'Andrade, Roy G. 1987. A Folk Model of the Mind. Holland, Dorothy \& Quinn, Naomi (eds.). Cultural Models in Language and Thought. Cambridge \& New York: Cambridge University Press, pp. 112-148.

Dawkins, Richard 1989. The Selfish Gene (2nd edition). Oxford \& New York: Oxford Universty Press.

EKG I = Eesti keele grammatika, I [The Estonian Grammar, Vol I]. 1995. Erelt, Mati \& Erelt, Tiiu \& Saari, Henn \& Viks, Ülle (eds.). Tallinn: Eesti Teaduste Akadeemia Eesti Keele Instituut.

Erikson, Erik H. (= Erik Homburger) 1982. The Life Cycle Completed: A Review. New York: Norton.

Fehr, Beverley \& Russell, James A. 1984. Concept of Emotion Viewed from a Prototype Perspective. Journal of Experimental Psychology, 113 (3), pp. 464-486.

Frijda, Nico H. \& Markam, Suprapti \& Sato, Kaori \& Wiers, Reinout W. 1995. Emotions and Emotion Words. Russell, James A. \& FernandezDols, Jose Miguel \& Manstead, Antony S. R. \& Wellenkamp, Jane C. (eds). Everyday Conceptions of Emotion: An Introduction to the Psychology, Anthropology and Linguistics of Emotion. Dordrecht (Netherlands) \& Boston: Kluwer Academia, pp. 121-143.

Geeraerts, Dirk \& Grondelaers, Stefan 1995. Looking back at Anger: Cultural Traditions and Metaphorical Patterns. Taylor, John R. \& MacLaury, Robert E. (eds). Language and the Cognitive Construal of the World. Trends in linguistics. Studies and monographs, 82. Berlin \& New York: Mouton de Gruyter, pp. 153-179.

Goldberg, Lewis R. 1993. The Structure of Phenotypic Personality Traits. American Psychologist, 48, pp. 26-34.

Haidt, Jonathan 2003. The Moral Emotions. Davidson, Richard J. \& Scherer Klaus R. \& Goldsmith, H. Hill (eds.). Handbook of Affective 
Sciences. Series in Affective Science. Oxford \& New York: Oxford University Press.

John, Oliver P. 1990. The "Big Five" Factor Taxonomy: Dimensions of Personality in the Natural Language and in Questionnaires. Pervin, Lawrence A. (ed.). Handbook of Personality: Theory and Research. New York: The Guilford Press, pp. 66-100.

Kästik, Ly 2000. Emotsioone väljendavate terminite subjektiivne ruum [The Subjective Space of Emotion Terms]. Unpublished diploma paper. Tallinn: Pedagogical University of Tallinn.

Kövecses, Zoltan 2000. Metaphor and Emotion: Language, Culture and Body in Human Feeling. Studies in Emotion and Social Interaction. Second Series. Cambridge \& New York: Cambridge University Press \& Paris: Editions de la Maison des sciences de l'homme.

Langacker, Roland W. 1987. Foundations of Cognitive Grammar I: Theoretical Prerequisites. Stanford: Stanford University Press.

Lakoff, George \& Johnson, Mark 1980. Metaphors we Live by. Chicago \& London: University of Chicago Press.

Lakoff, George 1987. Women, Fire and Dangerous Things: What Categories Reveal about the Mind. Chicago: University of Chicago Press.

Masing, Uku 2004. Keelest ja meelest: Taevapõdra rahvaste meelest ehk juttu boreaalsest hoiakust [About langauge and opinion. About the world view of the peoples of the heavenly raindeer, or about the boreal attitude]. Tartu: Ilmamaa.

Nõlvak, Aire \& Valk, Raivo 2003. Isiksus ja emotsioonid [Personality and emotions]. Allik, Jüri \& Realo, Anu \& Konstabel, Ken (eds.) Isiksusepsühholoogia [Psychology of Personality]. Tartu: Tartu Ülikooli Kirjastus, pp. 171-191.

Õim, Haldur 1997. Eesti keele mentaalse maailmapildi allikaid ja piirjooni [On the sources and margins of the Estonian worldview of mentality]. Erelt, Mati et al. (eds.). Pühendusteos Huno Rätsepale 28.12.1997 [A volume dedicated to Huno Rätsep]. Tartu Ülikooli eesti keele õppetooli toimetised $=$ Publications of the Department of Estonian of the University of Tartu, 7. Tartu: Tartu Ülikool, pp. 255-268.

Õim, Haldur 1999. How to Portray Emotions? Erelt, Mati (ed.) Estonian Typological Studies, III: Tartu Ülikooli eesti keele õppetooli toimetised, 11. Tartu: University of Tartu, pp. 231-252.

Orav, Heili 2000. Adjektiivid kui semantiline probleem: wordnet-tüüpi tesauruste koostamise kogemused. [Adjectives as a Semantic Problem: Some Experiences of Compiling Wordnet-Like Thesauri]. Hennoste, Tiit (ed.). Arvutuslingvistikalt inimesele. Tartu Ülikooli üldkeeleteaduse õppetooli toimetised, 1. Tartu: Tartu Ülikool, pp. 153-166.

Pajupuu, Hille 1994. A Nation's Autostereotype. "Oral Memory \& National Identity." Papers of the International Conference held in Tallinn, September 18-19, 1993. Tallinn: Vagabund, pp. 31-39. 
Pajupuu, Hille 1995. Eestlaste ja soomlaste kommunikatsioonikäitumise tagamaadest [On the Background of the Communicative Behaviour of the Estonians and Finns]. Keel ja Kirjandus, 11, pp. 767776.

Pajupuu, Hille 2005. Estonian National Stereotypes in Transition. Petkova, Diana \& Lehtonen, Jaakko (eds.). Cultural Identity in an Intercultural Context. Publications of the Department of Communication, No 27. Jyväskylä: Jyväskylän yliopisto, pp. 124-142.

Saareste, Albert (= Andrus) 1923. Eesti, eestlased ja Eesti keel (eessõna F. J. Wiedemanni eesti-saksa sõnaraamatule) [Estonia, Estonians and the Estonian Language (Foreword to Estonian-German Dictionary Compiled by F. J. Wiedemann)]. Wiedemann, Ferdinand Johann (comp.). Eesti-saksa sõnaraamat: Eesti kaardiga $=$ Estnisch-deutsches Wörterbuch: Mit einer Karte Eestis. Tartu: Eesti Kirjanduse Selts, p. XXVII.

Simka, Raissa 1950. Tähendusmuutusi tööd ja töölist kujutavas sõnavaras seoses ühiskondlikkude formatsioonide vaheldumisega [Some Semantic Changes in the Vocabulary Denotating Work and Workers in Relation with the Changes of Social Formations]. A manuscript in the University of Tartu.

Snir, Raphael \& Harpaz, Itzhak 2002. Employment Commitment and the Social Desirability Bias. The Journal of Social Psychology, 142 (5), pp. 635-644.

Solomon, Robert C. \& Stone, Lori D. 2002. On "Positive" and "Negative" Emotions. Journal for the Theory of Social Behaviour, 32 (4), pp. 417443.

Sutrop, Urmas 1996. Eesti keele värvussõnavara arengu põhijooni [Some Guidelines of the Development of Color Vocabulary in Estonian]. Keel ja Kirjandus, 10, pp. 661-674.

Sutrop, Urmas 2000. Basic Terms and Basic Vocabulary. Erelt, Mati (ed.). Estonian Typological Studies, IV. Tartu Ülikooli eesti keele õppetooli toimetised $=$ Publications of the Department of Estonian of the University of Tartu, 14. Tartu: Tartu Ülikool, pp. 118-145.

Sutrop, Urmas 2001. List Task and a Cognitive Salience Index. Field Methods, 13: 3, pp. 263-276.

Stearns, Peter N. 1994. American Cool: Constructing a TwentiethCentury Emotional Style. The History of Emotions Series. New York: New York University Press.

Tulving, Endel \& Schacter, Daniel L. 1990. Priming and Human Memory Systems. Science, 247, pp. 301-306.

Tuovila, Seija 2005. Kun on tunteet. Suomen kielen tunnesanojen semantiikkaa. Acta Universitatis Ouluensis, B Humaniora, 65. Oulu: Oulun Yliopisto.

Vainik, Ene 2001. Eestlaste emotsioonisõnavara [The Estonians' Vocabulary of Emotions]. MA thesis. Tartu: Tartu University (http:// www.eki.ee/teemad/emotsioon/emotsioon.pdf). 
Vainik, Ene 2002a. Emotions, Emotion Terms and Emotion Concepts in an Estonian Folk Model. Trames, 6 (4), pp. 322-341.

Vainik, Ene 2002b. Hot-blooded Estonians. On Estonians' Folk Category of Emotions. Folklore, 21, pp. 26-51.

Vainik, Ene 2002c. Millest on tehtud eestlaste emotsioonisõnavara? [What is the Estonians' Vocabulary of Emotions Made Of?] Keel ja Kirjandus, 8, pp. 537-553.

Vainik, Ene 2003. Soolisest ja ealisest spetsiifikast emotsioonisõnavara loetelu-katsetes [On the Tendencies Based on Gender and Age in the tasks of free listing of emotion terms]. Keel ja Kirjandus, 9, pp. 674-692.

Vainik, Ene 2004. Lexical Knowledge of Emotions: The Structure, Variability and Semantics of the Estonian Emotion Vocabulary. Dissertationes Linguisticae Universitatis Tartuensis, 5. Tartu: Tartu University Press.

van Goozen, Stephanie H.M \& Frijda, Nico H. 1993. Emotion Words Used in Six European Countries. European Journal of Social Psychology, 23, pp. 89-95.

Wierzbicka, Anna 1972. Semantic Primitives. Linguistische Forschungen, Bd. 22. Frankfurt a. M.: Athenäum.

Wierzbicka, Anna 1999. Emotions Across Languages and Cultures: Diversity and Universals. Studies in Emotion and Social Interaction: Second Series. Cambridge: Cambridge University Press. 